Presented 1991 IEEE Nuclear Science Symposium, BNL-46100

Santa Fe, NM, November 5-9, 1991

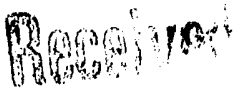

FEL O

Application of the Rapid Thermal Process:

Sintering the Sputtered Aluminum/Silicon

Contact in Silicon Detector Fabrication

Wei Chen, Zheng $\mathrm{Li}$ and $\mathrm{H}$. W. Kraner

Brookhaven National Laboratory, Upton, NY 11973

November 1991

*This research was supported by the U. S. Department of Energy:

Contract No, DE-AC02-76CH00016. 


\title{
Application of the Rapid Thermal Process: Sintering the Sputtered Aluminum/Silicon Contact in Silicon Detector Fabrication*
}

\author{
Wei Chen, Zheng $\mathrm{Li}$ and $\mathrm{H}$. W. Kraner \\ Brookhaven National Laboratory, Upton, NY 11973
}

BNL -46100

DE92 007594

\begin{abstract}
Rapid thermal process (RTP) sintering has been used in $\mathrm{p}^{+}-\mathrm{n}$ junction detector fabrication. For the same thickness of aluminum film and at the same RTP sintering condition, the leakage current of the $p^{+}-n$ junction detector with sputtered $A l$ gate showed at least a $50 \%$ improvement and no spiking phenomens were observed. RTP sintering in $4 \% \mathrm{H}_{2} / \mathrm{N}_{2}$ ambient passivates the defects introduced by sputtering and the damage caused by the ${ }^{60} \mathrm{Co}$ irradiation.
\end{abstract}

\section{INTRODUCTION}

Aluminum and its alloys are widely used for silicon detector metallization because of the ease of deposition, patternability, high conductivity, good adherence, bondability, easy availability and low cost [1].

Numerous techniques of depositing thin aluminum films have been developed by the processing industry, the most important among them heing evaporation, chemical vapor deposition and sputtering [2]. For high speed circuit applications, the series resistance between the gate contact and the gate itself must be very low. The common problem is the interdiffusion of $\mathrm{Si}$ and $\mathrm{Al}$ which is usually termed spiking. Spiking results in a clear short of the high impedance reverse diode characteristic. Therefore considerable effort has been given to improve the ohmic contact between the aluminum. film and the silicon substrate. The use of aluminum metallization sources having an alloy of a few percent silicon, or copper if the contact is to interface with copper electrodes, is a well known solution to the spiking ot intermetallic migration problem (Kierkendahl effect) $[3,4]$. The sputtering technique is expected to produce thin aluminum films with the minor constituent, Si, intact in the film, however, the effects of the dense ionization in the sputtering environment on the oxide passivations and oxide-silicon interface for detector configurations must be examined. Deal et al. [5] first described the effects of a low temperature anneal on the $\mathrm{SiO}_{2} / \mathrm{Si}$ interface and compared the role of hydrogen from both external $\left(\mathrm{H}_{2}\right.$ or $\left.\mathrm{N}_{2} \mathrm{H}_{2}\right)$ and ambient sources $\left(\mathrm{H}_{2} \mathrm{O}\right)$. Recently, attention has been directed in device processing toward sintering (a thermal cycle to $450^{\circ} \mathrm{C}$ in the Al-Si

*This research was supported by the U. S. Department of Energy: Contract Nu. DE-AC02-76CH00016. system) the Al-Si contact using a RTP which has been found to produce a highly reliable Al-Si contact [6-7]. This work reports results of using sputtered and evaporated contacts as well as their RTP sinterings. Comparisons of the leakage current difference and the $\mathrm{C}-\mathrm{V}$ characteristics between the two types of aluminum contacts before and after sintering were made in this study. The effects of ${ }^{60} \mathrm{Co}$ gamma radiation on the several contacts described were also studied.

\section{EXPERIMENTAL}

In this work, RTP was used to sinter Al metallization on the implanted $p^{+} n$ junction diode detectors [8] for both evaporated and sputtered Al-Si materials. Silicon materials used here were Wacker $\mathrm{n}\langle 111\rangle$ Si wafers with $0.1,0.165$ and $2-4 \mathrm{k} \Omega \mathrm{cm}$ resistivity. RTP is performed in two steps to eliminate possible overshooting of the temperature that may cause unexpected problems to the detectors (Fig. 1). In the first step the temperature was raised to $400^{\circ} \mathrm{C}$ for $40 \mathrm{sec}$. In the second step the temperature was raised to $450^{\circ} \mathrm{C}$ for either $20 \mathrm{sec}$ or $2 \mathrm{~min}$ on varying samples (Table I). The RTP unit is a PPC (Process Products Corp.) Model PTM-2016-M-2FFC. The ambient during the RTP is forming gas $\left(4 \% \mathrm{H}_{2} / \mathrm{N}_{2}\right)$.

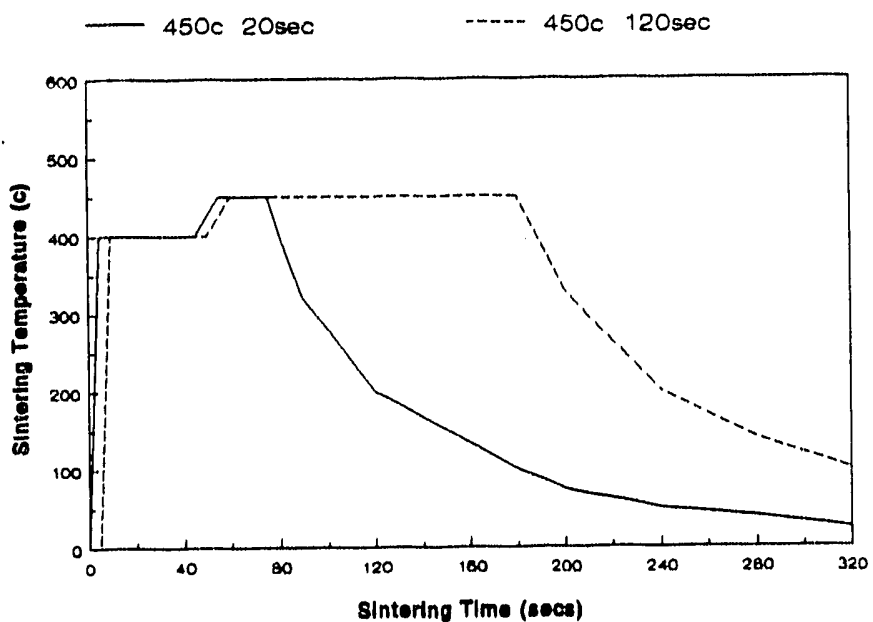

Fig. 1 Rapid Thermal Process Step

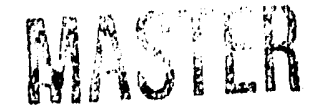


Table I. Comparisons of the leakage current for evaporated $\mathrm{Al}$ and sputtered $\mathrm{Al}$ before sintering and after sintering.

\begin{tabular}{|c|c|c|c|c|c|c|c|c|}
\hline \multirow{2}{*}{$\begin{array}{l}\text { Sample } \\
\text { No. }\end{array}$} & \multirow{2}{*}{ Material } & \multirow{2}{*}{ Al type } & \multirow{2}{*}{\multicolumn{2}{|c|}{$\begin{array}{l}\text { Sintering } \\
4 \% \mathrm{H}_{2} / \mathrm{N}_{2}\end{array}$}} & \multicolumn{2}{|c|}{ Leakage Current $\bar{I}_{L \mid 100 \mathrm{~V}}$} & \multirow{2}{*}{ Spiking } & \multirow{2}{*}{$\frac{\Delta I_{L}}{T_{L O}}$} \\
\hline & & & & & Before Sintering & After $\frac{\text { Sintering }}{I}_{L f}$ & & \\
\hline 83 & $\begin{array}{c}F Z n<111> \\
165 \mathrm{ncm}\end{array}$ & Sputtered & $\begin{array}{l}400^{\circ} \mathrm{C} \\
450^{\circ} \mathrm{C}\end{array}$ & $\begin{array}{l}40 \mathrm{sec} \\
2 \mathrm{~min}\end{array}$ & $53.8 \mathrm{nA}$ & $26.0 \mathrm{nA}$ & no & $-52 \%$ \\
\hline 63 & $\begin{array}{c}\mathrm{FZ} p<100> \\
2 \mathrm{kncm}\end{array}$ & Sputtered & $\begin{array}{l}400^{\circ} \mathrm{C} \\
450^{\circ} \mathrm{C}\end{array}$ & $\begin{array}{l}40 \mathrm{sec} \\
2 \mathrm{~min}\end{array}$ & $65.8 \mathrm{nA}$ & $30.5 \mathrm{nA}$ & no & $-54 \%$ \\
\hline 106 & $\begin{array}{c}\mathrm{FZ} n<111> \\
4 \mathrm{k} \Omega \mathrm{cm}\end{array}$ & Sputtered & $\begin{array}{l}400^{\circ} \mathrm{C} \\
450^{\circ} \mathrm{C}\end{array}$ & $\begin{array}{l}40 \mathrm{sec} \\
2 \mathrm{~min}\end{array}$ & $142.4 \mathrm{nA}$ & $35.3 \mathrm{nA}$ & no & $-75 \%$ \\
\hline 107 & $\begin{array}{c}\mathrm{FZ} n<111> \\
4 \mathrm{k} \cap \mathrm{cm}\end{array}$ & Sputtered & $\begin{array}{l}400^{\circ} \mathrm{C} \\
450^{\circ} \mathrm{C}\end{array}$ & $\begin{array}{l}40 \mathrm{sec} \\
2 \mathrm{~min}\end{array}$ & $146.3 \mathrm{nA}$ & $46.7 \mathrm{nA}$ & no & $-68 \%$ \\
\hline 76 & $\begin{array}{c}\mathrm{CZn}<111> \\
>100 \mathrm{Rcm}\end{array}$ & Sputtered & $\begin{array}{l}400^{\circ} \mathrm{C} \\
450^{\circ} \mathrm{C}\end{array}$ & $\begin{array}{l}40 \mathrm{sec} \\
20 \mathrm{sec}\end{array}$ & $98.8 \mathrm{nA}$ & $26.4 \mathrm{nA}$ & no & $-73 \%$ \\
\hline 80 & $\begin{array}{c}\mathrm{FZn}<111> \\
165 \mathrm{ncm}\end{array}$ & Evaporated & $\begin{array}{l}400^{\circ} \mathrm{C} \\
450^{\circ} \mathrm{C}\end{array}$ & $\begin{array}{l}40 \mathrm{sec} \\
20 \mathrm{sec}\end{array}$ & $87.0 \mathrm{nA}$ & $91.5 \mathrm{nA}$ & no & $5 \%$ \\
\hline 65 & $\begin{array}{c}\mathrm{FZ} p<100> \\
2 \mathrm{k} \Omega \mathrm{cm}\end{array}$ & Evaporated & $\begin{array}{l}400^{\circ} \mathrm{C} \\
450^{\circ} \mathrm{C}\end{array}$ & $\begin{array}{l}40 \mathrm{sec} \\
2 \mathrm{~min}\end{array}$ & $2.2 \mu \mathrm{A}$ & $51.7 \mu \mathrm{A}$ & yes & $>100 \%$ \\
\hline 61 & $\begin{array}{c}\mathrm{FZ} p<111> \\
5 \mathrm{k} \Omega \mathrm{cm}\end{array}$ & Evaporated & $\begin{array}{l}400^{\circ} \mathrm{C} \\
450^{\circ} \mathrm{C}\end{array}$ & $\begin{array}{l}40 \mathrm{sec} \\
2 \mathrm{~min}\end{array}$ & $46.5 \mathrm{nA}$ & $70.0 \mu \mathrm{A}$ & yes & $>100 \%$ \\
\hline 62 & $\begin{array}{c}\mathrm{FZ}_{\mathrm{p}}<111> \\
5 \mathrm{k} \Omega \mathrm{cm}\end{array}$ & Evaporated & $\begin{array}{l}400^{\circ} \mathrm{C} \\
450^{\circ} \mathrm{C}\end{array}$ & $\begin{array}{l}40 \mathrm{sec} \\
20 \mathrm{sec}\end{array}$ & $57 \mathrm{nA}$ & mAs & yes & $>100 \%$ \\
\hline 78 & $\begin{array}{c}\mathrm{CZ} n<111> \\
>100 \Omega \mathrm{cm}\end{array}$ & Evaporated & $\begin{array}{l}400^{\circ} \mathrm{C} \\
450^{\circ} \mathrm{C}\end{array}$ & $\begin{array}{l}40 \mathrm{sec} \\
20 \mathrm{sec}\end{array}$ & $1.3 \mu \mathrm{A}$ & $2.2 \mu \mathrm{A}$ & yes & $69 \%$ \\
\hline
\end{tabular}

Pure Al was evaporated from a low alkali tungsten filament in a $10^{-7}$ Torr oil-free, ion-pumped vacuum system. A dc sputtering system was used for sputtered Al contacts. Argon gas pressure was kept at $1.0 \mathrm{~m}$ Torr during the sputtering. An aluminum target containing $2 \%$ silicon was used to produce an $\mathrm{Al}-\mathrm{Si}$ alloy contact; it will be shown that co-evolution of $\mathrm{Al}$ and Si can be achieved only by the sputtering method. The thickness of the film deposited is about $2500 \AA$ for both evaporation and sputtering.

In order to confirm the incorporation of silicon in the aluminum metallization, samples of the evaporated and sputtered Al films were produced on a clean carbon electron microscope stub and observed in the SEM with a high resolution $\mathrm{Si}(\mathrm{Li}) \mathrm{x}$-ray detector to measure the deposited $\mathrm{Al}$ and $\mathrm{Si}$ by their characteristic $\mathrm{K} x$-rays at 1.55 and $1.74 \mathrm{keV}$, respectively. Figure 2 shows the spectra from the evaporated sample and the sputtered sample. In a difficult measurement, the small Si peak can be seen on the high energy side of the major aluminum peak in the sputtered sample; silicon cannot really be discerned in the evaporated sample. Calibrations indicate that the percentage of Si deposited is $1.2 \% \pm 0.2 \%$.

MOS capacitors with evaporated $\mathrm{Al}$ gates and sputtered $\mathrm{Al}$ Si gates were also fabricated to study the effect of RTP sintering on the oxide damage introduced by sputtering. Several MOS devices have also been prepared for radiation hardening (or softening) experiments using neutron transmutation doped $[1,1,1]$ n-type Wacker silicon with $\rho \geq 5 \mathrm{~K} \Omega$-cm resistivity. Oxide thicknesses were about $5000 \AA$. Four $\mathrm{mm}$ diameter circles of Al were evaporated to a thickness of $2500 \AA$. These MOS structures were divided into two groups: Group A was measured as fabricated and Group B underwent RTP before irradiation by ${ }^{60} \mathrm{Co}$ gamma rays up to $40 \mathrm{k}$-rad. Each group could then be sintered after irradiation and measured to determine if some oxide hardening (or softening) was introduced by the RTP.

\section{RESULTS AND DISCUSSION}

Table I shows results of leakage currents of detectors with evaporated and sputtercd $\mathrm{Al}$ before and after sintering. Leakage currents of detectors with sputtered Al contacts are shown to improve at least $50 \%$ after sintering and no spiking phenomena were observed for a wide variety of materials and fabrication runs. Sputtering indeed produced thin Al-Si alloy film. However, the leakage currents of detectors with evaporated $\mathrm{Al}$ contacts increased significantly after sintering and observable spiking occurred in some cases. The aluminum metal pellet for the basket in the vacuum evaporator did indeed include $2 \% \mathrm{Si}$, however the $\mathrm{Si}$ was not co-evaporated with the major component, aluminum. Although evaporated confacts are expected to be considerably less potentially harmful to oxide layer, the spiking occured at an oxide-Si edge as we have observed in evaporated Al situation. No spiking after sintering was observed in detectors with $\mathrm{Al}$ sputtered metallizations even in detectors in which $\mathrm{Al}$ step-covers the oxide edges. The step coverage Al contact, in fact, is the 


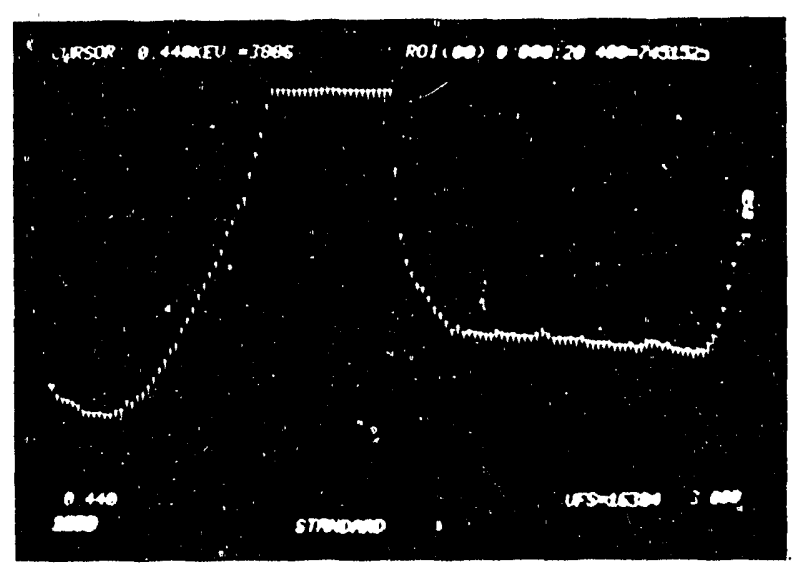

(a) Evaporated

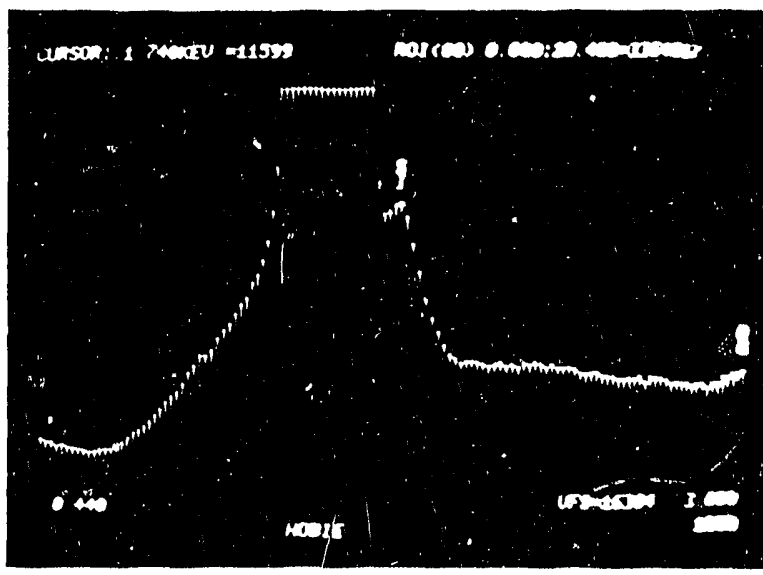

(b) Sputtered

Fig. 2 The energy spectra from the evaporated and sputtered sample.

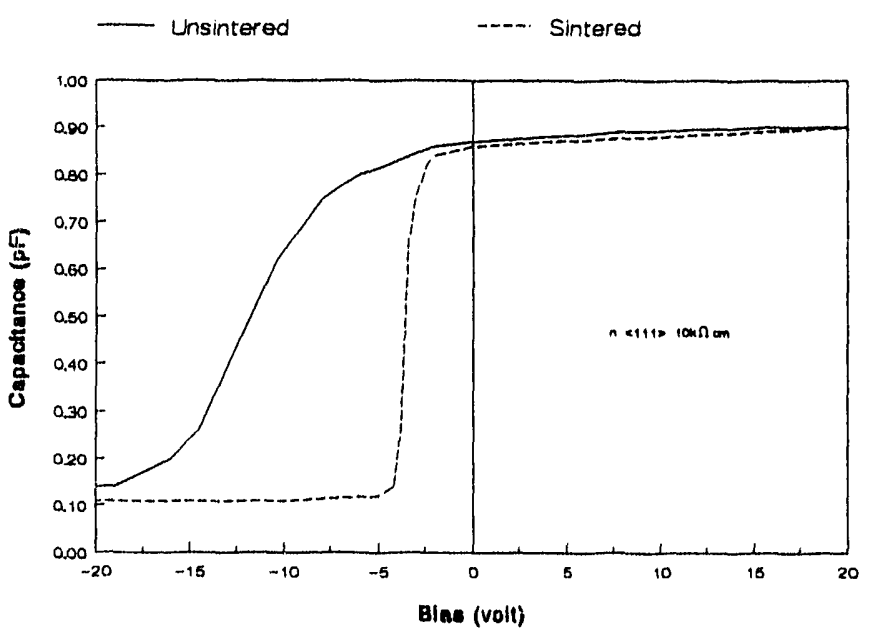

Fig. 3 C(V) Curve of MOS Capacitor for Sputtered Al Gate preferable metallization configuration becouse the contact acts as a field plate to deplete the surface charge and reduce the surface-controlled potential gradient at the junction edge. Therefore, sputtering films provide better step coverage. Using sputtered Al to step-cover the oxide edges, which minimizes the surface leakage current and improves the breakdown voltage, has become a standard metallization step in our detector fabrication process.

Data of flatband voltage changes of MOS capacitors with evaporated and sputtered $\mathrm{Al}$ gates before and after sintering is shown in Table II. The flatband voltage of a MOS capacitor with sputtered $\mathrm{Al}$ gate is found to be larger than the one with an evaporated $\mathrm{Al}$ gate before rapid thermal sintering. Spuitering clearly creates more positive charges in the oxide layer due to the damage caused by energetic ion bombardment. After rapid thermal sintering, however, both the flatband voltage shift $\Delta \mathrm{V}_{\mathrm{FB}}$ and the stretchout $\delta \mathrm{V}_{\mathrm{FB}}$ of the MOS capacitor with sputtered $\mathrm{Al}$ gates became comparable to those with evaporated $\mathrm{Al}$ gates, as shown in Figs. 3 and 4. Table III shows the data of flatband voltage changes of MOS capacitors with evaporated $\mathrm{Al}$ gates before and after radiation and the effect of RTP treatment. A large flatband shift $\left(\Delta V_{F B}\right)$ has been found for all capacitors in Group $A$ and $B$ except capacitor $B 4$. This indicates that a large amount of positive charge was created in the oxide layer after irradiation. In the B4 case (irrajiated with no bias), some positive charge may have been neutralized after irradiation into neutral traps. However, after RTP sintering, the flatband voltages became comparable with those prior to irradiation for capacitors in both groups. The same improvement was found for the stretchout of the C-V characteristic after RTP sintering indicating the annealing out of interface states. Rapid thermal sintering process, with its hydrogen rich high temperature ambient, proves to passivate the interface states at the $\mathrm{Si} / \mathrm{SiO}_{2}$ interface and remove positive charge in the oxide layer introduced by both sputtering and ${ }^{60} \mathrm{Co}$ irradiation. Since the surface leakage current (via, i.e., the junction edges) is proportional to the surface states $N_{i t}: i_{s}=e n_{i}\left(\sigma v_{t h} N_{i t}\right)$, a decrease of $I_{s}$ after sintering is expected and this may be the cause of the observed overall leakage current decrease after sintering for detectors with sputtered $\mathrm{Al}$ contacts.

In conclusion, we found that the rapid thermal sintering process in a $4 \% \mathrm{H}_{2} / \mathrm{N}_{2}$ ambient passivates the defects introduced by sputtering and the damage caused by the ${ }^{60} \mathrm{Co}$ irradiation in the oxide layer. No spiking was observed for detectors with sputtered $\mathbf{A l}$ contact after RTP sintering. The sputtered film maintains a composition close to the source material and provides better step coverage. Thus Al-Si alloy is transferred as the metallization, spiking is largely eliminated as expected and good quality junction detectors are produced. RTP combined with sputtering technique fulfills the requirements of Al-Si contact: produces a low series resistance, gives a very bondable contact land and because of its short time duration does not influence other dopant species in the device. Sputtering and rapid thermal sintering have been accepted as the standard means of metallization in our detector processing. 
Table II. Comparison of the flatband voltage and the stretchout between evaporated $\mathrm{Al}$ and sputtered $\mathrm{Al}$.

\begin{tabular}{|c|c|c|c|c|c|c|c|c|}
\hline \multirow{2}{*}{$\begin{array}{c}\text { Material } \\
5000 \AA\end{array}$} & \multicolumn{2}{|c|}{$\Delta V_{F B}$ (before sintering) } & \multicolumn{2}{|c|}{$\Delta V_{F B}$ (after sintering) } & \multicolumn{2}{c|}{$\delta V_{F B}$ (before sintering) } & \multicolumn{2}{c|}{$\delta V_{F B}$ (after sintering) } \\
\cline { 2 - 8 } & $\begin{array}{c}\text { Evaporated } \\
\mathrm{Al}\end{array}$ & $\begin{array}{c}\text { Sputtered } \\
\mathrm{Al}\end{array}$ & $\begin{array}{c}\text { Evaporated } \\
\mathrm{Al}\end{array}$ & $\begin{array}{c}\text { Sputtered } \\
\mathrm{Al}\end{array}$ & $\begin{array}{c}\text { Evaporated } \\
\mathrm{Al}\end{array}$ & $\begin{array}{c}\text { Sputtered } \\
\mathrm{Al}\end{array}$ & $\begin{array}{c}\text { Evaporated } \\
\mathrm{Al}\end{array}$ & $\begin{array}{c}\text { Sputtered } \\
\mathrm{Al}\end{array}$ \\
\hline $\begin{array}{c}\mathrm{n}<111> \\
2-4 \mathrm{kncm}\end{array}$ & $-6.4 \mathrm{~V}$ & $-27.4 \mathrm{~V}$ & $-3.9 \mathrm{~V}$ & $-3.6 \mathrm{~V}$ & $0.48 \mathrm{~V}$ & $3.60 \mathrm{~V}$ & $0.24 \mathrm{~V}$ & $0.27 \mathrm{~V}$ \\
\hline $\begin{array}{c}\mathrm{n}<111> \\
10 \Omega \mathrm{cm}\end{array}$ & $-3.7 \mathrm{~V}$ & $-10.4 \mathrm{~V}$ & - & $-3.4 \mathrm{~V}$ & $0.80 \mathrm{~V}$ & $4.40 \mathrm{~V}$ & - & $0.40 \mathrm{~V}$ \\
\hline $\begin{array}{c}\mathrm{p}<100> \\
2 \mathrm{k} \Omega \mathrm{cm}\end{array}$ & $-12.0 \mathrm{~V}$ & $-26 \mathrm{~V}$ & -8.2 & $-1.23 \mathrm{~V}$ & $0.90 \mathrm{~V}$ & $13.00 \mathrm{~V}$ & $3.00 \mathrm{~V}$ & $0.36 \mathrm{~V}$ \\
\hline
\end{tabular}

Table III. Comparison of Flatband Voltage for Radiated MOS Capacitors Before and After Sintering

\begin{tabular}{|c|c|c|c|c|c|c|c|c|c|}
\hline \multirow{2}{*}{$\begin{array}{c}\text { Sample } \\
\text { No. }\end{array}$} & \multirow{3}{*}{ Bias } & \multicolumn{2}{|c|}{$\begin{array}{c}\Delta V_{F B} \\
\text { (before radiation) }\end{array}$} & \multicolumn{2}{c|}{$\begin{array}{c}\delta V_{F B} \\
\text { (before radiation) }\end{array}$} & \multicolumn{2}{c|}{$\begin{array}{c}\Delta V_{F B} \\
\text { (after radiation) } \\
\text { (40 K-rad) }\end{array}$} & $\begin{array}{c}\delta V_{F B} \\
\text { (after radiation) } \\
\text { (40 K-rad) }\end{array}$ \\
\cline { 2 - 10 } & & $\begin{array}{c}\text { No } \\
\text { Sintering }\end{array}$ & Sintering & $\begin{array}{c}\text { No } \\
\text { Sintering }\end{array}$ & Sintering & $\begin{array}{c}\text { Before } \\
\text { Sintering }\end{array}$ & $\begin{array}{c}\text { After } \\
\text { Sintering }\end{array}$ & $\begin{array}{c}\text { Before } \\
\text { Sintering }\end{array}$ & $\begin{array}{c}\text { After } \\
\text { Sintering }\end{array}$ \\
\hline A1 & + & $-4.9 \mathrm{~V}$ & - & $0.3 \mathrm{~V}$ & - & $-12.8 \mathrm{~V}$ & $-3.7 \mathrm{~V}$ & $6.1 \mathrm{~V}$ & $0.7 \mathrm{~V}$ \\
\hline A2 & - & $-5.5 \mathrm{~V}$ & - & $0.3 \mathrm{~V}$ & - & $-7.8 \mathrm{~V}$ & $-3.9 \mathrm{~V}$ & $2.1 \mathrm{~V}$ & $0.6 \mathrm{~V}$ \\
\hline A3 & 0 & $-4.9 \mathrm{~V}$ & - & $0.3 \mathrm{~V}$ & - & $-8.5 \mathrm{~V}$ & $-3.7 \mathrm{~V}$ & $1.9 \mathrm{~V}$ & $0.8 \mathrm{~V}$ \\
\hline A4 & 0 & $-5.0 \mathrm{~V}$ & - & $0.3 \mathrm{~V}$ & - & $-8.7 \mathrm{~V}$ & $-3.7 \mathrm{~V}$ & $2.1 \mathrm{~V}$ & $0.6 \mathrm{~V}$ \\
\hline A5 & + & $-6.7 \mathrm{~V}$ & - & $0.4 \mathrm{~V}$ & - & $-12.6 \mathrm{~V}$ & $-7.5 \mathrm{~V}$ & $5.9 \mathrm{~V}$ & $0.4 \mathrm{~V}$ \\
\hline A6 & - & $-5.6 \mathrm{~V}$ & - & $0.4 \mathrm{~V}$ & - & $-9.4 \mathrm{~V}$ & $-3.5 \mathrm{~V}$ & $2.1 \mathrm{~V}$ & $0.7 \mathrm{~V}$ \\
\hline B1 & + & $-9.7 \mathrm{~V}$ & $-10.4 \mathrm{~V}$ & $0.3 \mathrm{~V}$ & $1.1 \mathrm{~V}$ & $-15.2 \mathrm{~V}$ & $-6.6 \mathrm{~V}$ & $5.9 \mathrm{~V}$ & $0.6 \mathrm{~V}$ \\
\hline B2 & + & $-3.8 \mathrm{~V}$ & $-4.1 \mathrm{~V}$ & $0.3 \mathrm{~V}$ & $6.2 \mathrm{~V}$ & $-12.6 \mathrm{~V}$ & $-3.2 \mathrm{~V}$ & $6.5 \mathrm{~V}$ & $0.7 \mathrm{~V}$ \\
\hline B3 & -10 & $-5.3 \mathrm{~V}$ & $-6.1 \mathrm{~V}$ & $0.3 \mathrm{~V}$ & $0.5 \mathrm{~V}$ & - & $-4.3 \mathrm{~V}$ & - & $0.2 \mathrm{~V}$ \\
\hline B4 & 0 & $-6.0 \mathrm{~V}$ & $-6.9 \mathrm{~V}$ & $0.3 \mathrm{~V}$ & $0.6 \mathrm{~V}$ & $-2.7 \mathrm{~V}$ & $-5.1 \mathrm{~V}$ & $1.8 \mathrm{~V}$ & $0.2 \mathrm{~V}$ \\
\hline
\end{tabular}

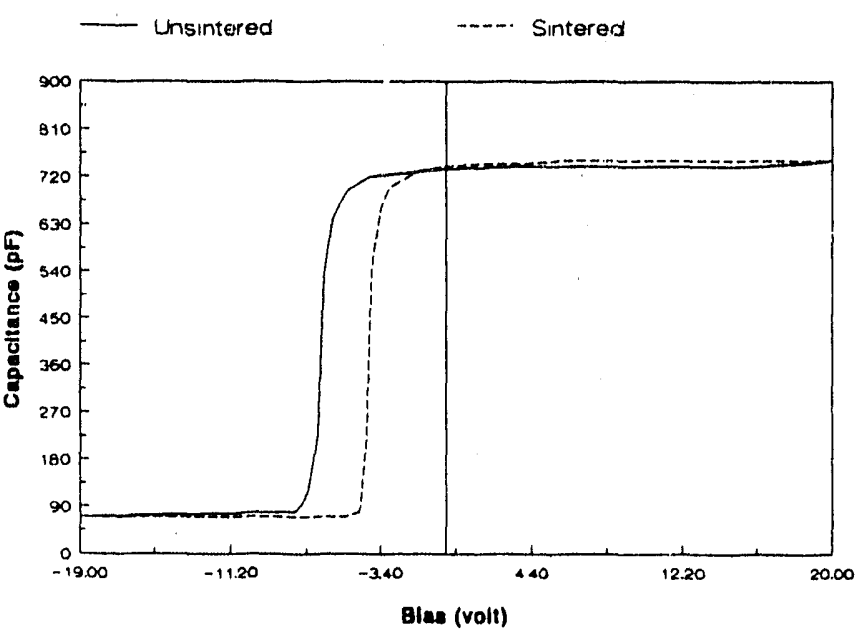

Fig. $4 \mathrm{C}(\mathrm{V})$ Curve of MOS Capacitor for Evaporated Al Gate

\section{ACKNOWLEDGMENTS}

It is a pleasure to thank Dr. John Warren, BNL, for measuring the $\mathrm{Si}$ concentration in the aluminum metallizations and James A. Kierstead for his help with the irradiations. We appreciate the help given by Dr. Eckhart Fretwurst of the University of Hamburg during his visit to this laboratory. 


\section{REFERENCES}

[1] Norman G. Einspruch, VLSI Handbook, Academic Press, New York, p. $435-453$ (1985).

[2] Richard C. Jaeger, "Introduction to Microelectronic Fabrication," Addison-Wesley Publ. Co., New York, Vol. V, p. 107130 (198.9).

[3] D. Pramunik and A. N. Saxena, "VLSI Metallization Using Aluminum and Its Alloys," Part I, Sólid State Technol. 26 (1), 127-333 (1983).

[4] D. Pramanik and A. N. Saxena, "VLSI Metallization Using Aluminum and Its Alloys," Part II, Solid State Technol. 26 (3), 131-137 (1983).
[5] B. E. Deal, E. L. MacKenna, and P. L. Castro, "Characteristics of Fast Surface States Associated with $\mathrm{SiO}_{2}-\mathrm{Si}$ and $\mathrm{Si}_{3} \mathrm{~N}_{4}-\mathrm{SiO}_{2}-\mathrm{Si}$ Structures," J. Electrochem. Soc., 116, 997 (1969).

[6] E. Umemura, H. Onoda and S. Madokoro, "High Reliable Al-Si Alloy/Si Contacts by Repid Thermal Sinter," Proc. 26th Annual Conf. on Reliability Physics, IEEE Publ., New York, p. 230-233 (1988).

[7] Cunli Chen, Hui Ping and Lianzhu Li, "Rapid Thermal Annealing of Al-Si Contucts," Chinese J. Semiconductors 9 (3), 317 320 (1988).

[8] Z. Li and H. W. Kraner, "Gettering in High Resistive Float Zone Silicon Wafers for Silicon Detector Applications," IEEE Trans. Nucl. Sci. 37 (1), 290-292 (1989). 

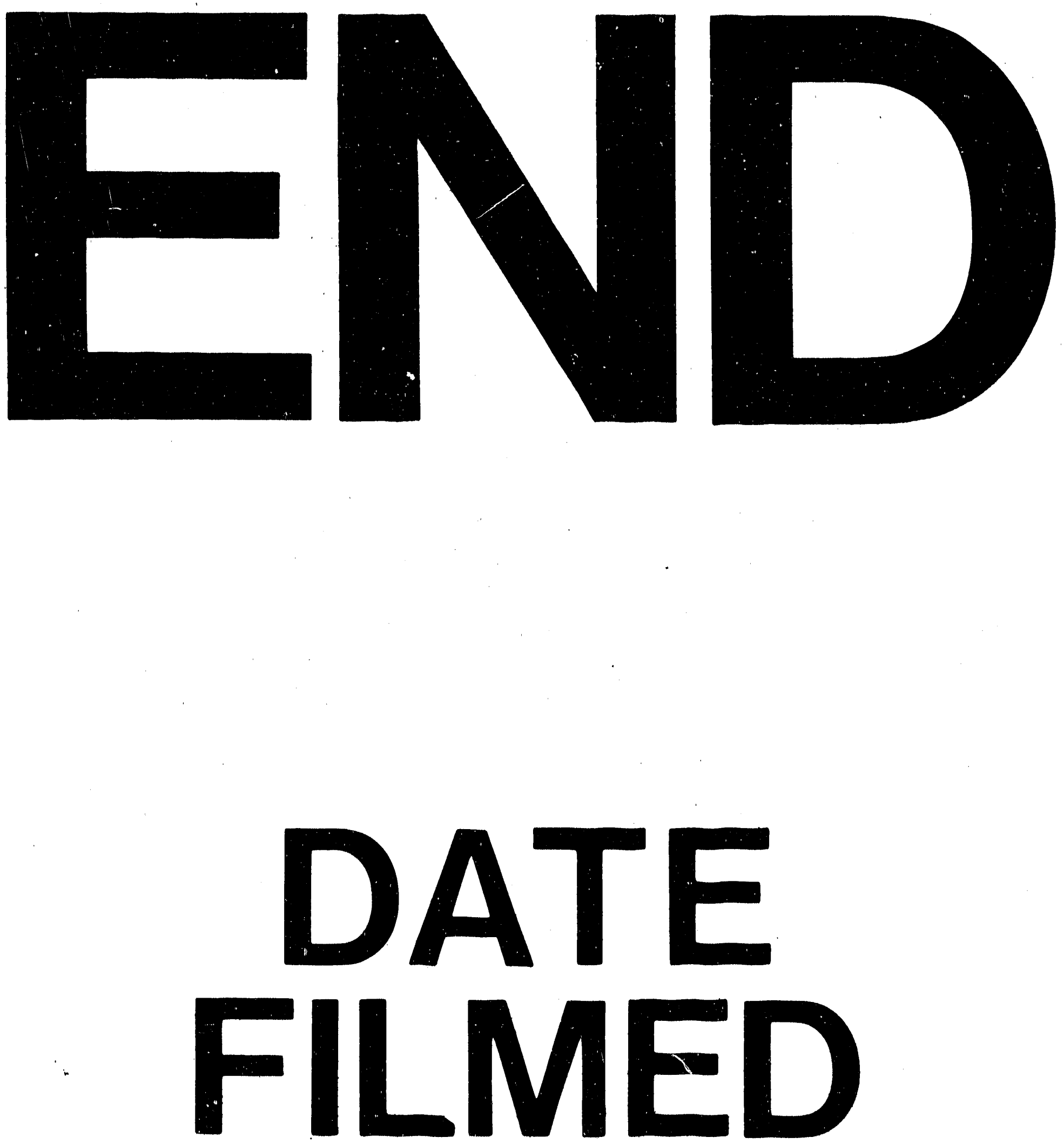

1

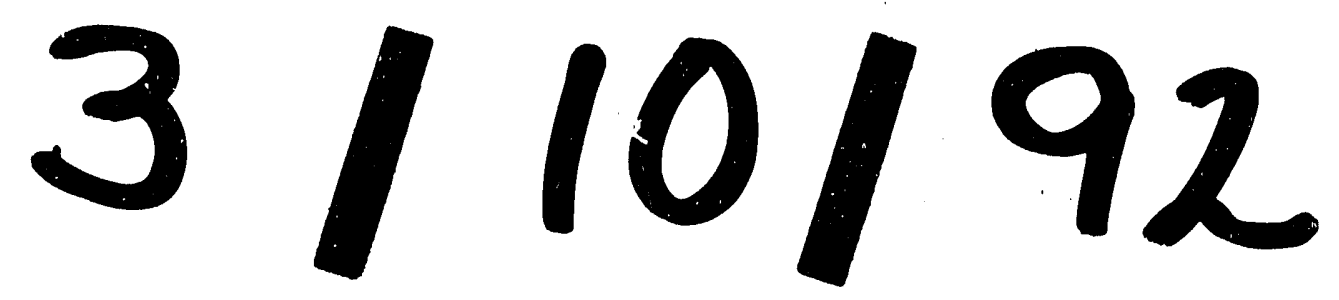


